\title{
Direct Parliamentarianism: An Analysis of the Political Values Embedded in Rousseau, the 'Operating System' of the Five Star Movement
}

\section{Marco Deseriis}

Marie Curie Fellow, Institute of Humanities and Social Sciences, Scuola Normale Superiore, Firenze, Italy, marco.deseriis@sns.it

Abstract: This article focuses on the technological affordances and use of Rousseau, the decision-making platform of the second largest Italian political party, the Five Star Movement. Crossing an empirical observation of the platform's functionalities with data regarding its use and qualitative data collected during the 2016 and 2017 national meetings of the Five Star Movement, the essay argues that Rousseau supports an emerging "direct parliamentarianism," which allows party members to entertain an ostensibly direct relationship with the party in public office, at the expense, however, of deliberative processes that may allow them to influence the party agenda. Thus Rousseau leaves the deliberative, and strictly parliamentary moment in the hands of elected representatives and party leaders, leaving to the party base the task of choosing between options that have been defined elsewhere.

Keywords: Five Star Movement; Rousseau; decision-making platform; direct democracy; direct parliamentarianism; crowdsourced lawmaking.

Acknowledgment: Research for this article was funded by a Marie Curie Individual Fellowship grant under the Horizon 2020 program of the European Commission (H2020-MSCA-IF-2015 grant agreement no. 7101513). The author would like to thank Lorenzo Mosca for his useful comments.

\section{Introduction}

With over 140,000 registered users as of August 2017 (Casaleggio 2017), Rousseau is one of the world's largest online platforms for political participation and collaborative law-making. ${ }^{1}$ Owned

${ }^{1}$ Rousseau can be accessed at https://rousseau.movimento5stelle.it. As of October 30, 2017, participa.podemos.info, the online platform of the Spanish party Podemos, declares over 487,000 registered users. The portal, however, embeds less functionalities than Rousseau, especially in the area of collaborative or crowdsourced law-making. 
and developed by the Five Star Movement (5SM), the second largest Italian political party, Rousseau allows its users to select candidates via online primaries, vote the party program, provide feedback to elected representatives on draft legislation, publicize local events, and submit their own legislative proposals to Members of Parliament. Further the platform allows 5SM city councillors and regional councillors to take online courses on the regulatory frameworks of local authorities and exchange administrative acts with other councillors across the nation.

In this article I am going to argue that the integration of these functionalities within the same platform embodies a particular model of political participation and democracy. At a first sight, such model reflects the programmatic statements of the 5SM co-founders Beppe Grillo and Gianroberto Casaleggio. As we will see, the 5SM founders frame the participation of citizens to institutional decision making via the Internet as a modern form of direct democracy and a positive check on the autonomy of elected representatives. At a closer look, however, the platform combines direct democracy measures with consultation procedures typical of representative democracy. My wager is that this combination produces an emerging form of direct parliamentarianism, that is, a hybrid institutional arrangement wherein the direct participation of citizens to policy making does not reduce the autonomy of elected representatives, but on the contrary reinforces it and legitimizes it.

To support this argument, I will contrast the founders' programmatic statements to three kinds of data: an empirical analysis of Rousseau's affordances; quantitative data regarding the use of Rousseau; and qualitative data I have personally collected through fieldwork at two national meetings of the 5SM in Palermo in 2016 and in Rimini in 2017. The affordance analysis begins from the notion that, far from being technologically neutral, the design of any participation platform is inflected with certain political values, that is, a specific conception of democracy and of political representation. In this case, the frequent recourse to voting and the lack of in-platform discussion tools suggests that Rousseau privileges preference aggregation over processes of opinion formation, decision-making over deliberation.

During their presentations of the platform in Palermo and Rimini, the MPs who oversee the lawmaking areas of Rousseau confirmed that the platform has been designed to allow members to make decisions rather than for extended intra-party conversations. ${ }^{2}$ Yet data concerning platform usage show that voter turnout and the volume of member feedback on draft legislation have been steadily declining since 2014, and this in spite of the growth of the user base. As we will see, the only area in which participation has not been declining is Lex Members, which allows Rousseau's registered users to submit their own ideas for a bill of law. Finally, whereas the party leadership presents Rousseau as a pioneering experiment in direct democracy, the party in public office does

${ }^{2}$ In these two circumstances, I was able to ask questions to the representatives as a member of the public. In Rimini I also distributed a questionnaire on Rousseau to platform users. This gave me the opportunity to strike informal conversations with several party activists and to glean additional insights on platform usage. Some of these insights are discussed in this article. Others will be discussed in a subsequent article, where I will also analyse the questionnaire data. 
not seem to have allocated sufficient resources to screen the proposals uploaded in Lex Members and to respond consistently to the members' comments in the consultative areas of the platform. In this respect, the analysis of the platform affordances and of its usage patterns cannot be decoupled from an analysis of the organizational practices that are meant to support user participation.

Before analyzing these data more in detail, I will briefly recapitulate the history of the 5SM and link its networked organizational structure to the co-founders' vision of a politics without traditional parties and intermediaries.

\section{Brief History of the $5 \mathrm{SM}$}

With $25.5 \%$ of the vote and 163 elected MPs at the general elections of 2013, the Five Star Movement is the second largest Italian political party. After the expulsion of several deputies and senators, due to a series of internal conflictes in the early phase of the legislature, the 5SM still controls 130 MPs. These are part of a wider contingent of 2.200 representatives elected on various levels of the public administration, including 15 Members of the European Parliament and 36 majors, among which the mayors of Rome and Turin (Casaleggio 2017). In 2017, the 5SM has been steadily polling between $25 \%$ and $30 \%$, slightly ahead of the ruling Democratic Party, and is well positioned to be the first party at the general elections of 2018.

Although winning the relative majority may not be sufficient for the 5SM to form a government, political analysts agree that the Movement can no longer be considered as a protest party insofar as it has been able to exploit its "purely populist" rejection of the Left-Right divide (Tarchi 2015) and "ideological flexibility" (Manucci and Amsler 2017) to stably occupy the center of the Italian political spectrum. Indeed since its foundation in 2009, the 5SM has undergone a slow but continuous process of institutionalization (Bordignon and Ceccarini 2015; Tronconi 2016), which appears to be in tension with the virulent anti-establishment rhetoric of his co-founder and charismatic leader Beppe Grillo.

In many ways, Grillo's own biography epitomizes the widespread distrust, if not hatred, Italians harbor towards the political class - as demonstrated by the stunning success of the book $L a$ Casta, an investigation into the lavish lifestyle and corrupt practices of Italian politicians (Rizzo and Stella 2007). Once a popular TV comedian, Grillo was banned from public television in 1986, after he satirized the then ruling Socialist Party (PSI) on a prime-time TV show, accusing his leaders of corruption (Scanzi 2008). After the ban-which was directly ordered by the PSI Prime Minister Bettino Craxi-Grillo began touring Italy with a series of theater shows. The 1992 corruption scandal known as Bribeville (Tangentopoli), which saw the PSI at the center of a vast and institutionalized system of briberies, proved to many the prophetic character of Grillo's satire. In 2005 Grillo launched the blog beppegrillo.it, which quickly became one of the most visited and influential blogs in the world (Mello 2013). Capitalizing on the blog's mass following Grillo launched his first political initiatives. These included Clean Parliament (a petition to remove from Parliament the MPs who are convicted of a crime by a final judgment) and the V-Days of 2007 and 2008, two massive rallies held in Bologna and Turin, respectively, against the corruption of the political class and of the Italian media system (Oggiano 2012: 94-119). 
Because the blog was an inadequate tool for organizational purposes, Gianroberto CasaleggioGrillo's blog administrator, and CEO of the Web marketing company Casaleggio Associatilaunched in July 2005 the first Meetup group "Friends of Beppe Grillo" in Milan. In the following months, dozens of Meetup groups mushroomed all over the country. In 2009, taking inspiration from Howard Dean's use of Meetup as the grassroots backbone of his campaign for the primaries of the U.S. Democratic Party, Casaleggio thought of mobilizing the Italian Meetups to support Grillo's bid to national secretary of the Italian Democratic Party (PD) - a party that had been founded in 2007 to unify the centre-left. As soon as the PD leadership rejected Grillo's membership application, crippling his plan to run for the party primaries, Grillo and Casaleggio founded the 5SM as an independent political party (Ibid., 120-126).

After the first successful bids at the local and regional elections of 2009-12, the 5SM became a political organization with national ambitions. The electoral success of 2013 produced, almost overnight, a new national ruling group. As is the case with many contemporary parties, this party in public office has acquired a growing importance as compared to the party on the ground and the party in central office (Katz and Mair 2002). However, in the 5SM, the latter is still able to control the party in public office by appointing the head of the communication staff of the parliamentary groups, which reports directly to the Casaleggio Associati. This is a "key figure, who has the task of coordinating the activities of the parliamentary group or consiliary group with the national website and the blog of Beppe Grillo" (Passarelli et al. 2017: 189). Further, the party in central office controls the bulk of party decisions precisely through Rousseau. Paradoxically, however, a key function of Rousseau is to allow the party on the ground to contribute directly to the writing of laws, thus developing a relation with the party in public office that should bypass the mediation of the party in central office.

\section{The Double Rejection of Party Politics and the Free Mandate}

Since the beginning, the organizational structure of the nascent party took on peculiar features. Not only did the Meetup groups met in unconventional spaces such as sport clubs, bars, public spaces and private apartments, but the Movement's legal home initially coincided with Beppe Grillo's home address. More importantly, most 5SM members identified the Url beppegrillo.it as the true headquarter of the Movement. The "Non Statute," the constitutive document of the 5SM, acknowledges the central role of the Internet in expanding participation in the political process:

The Five Star Movement is not a political party nor it intends to become one in the future. It wants to realize an efficient and effective exchange of opinions and democratic debate outside of associational and party bonds, and without the mediation of directive or representative organisms, recognizing to the totality of the Network users the role of government and orientation ordinarily attributed to the few (Movimento 5 Stelle 2016: 3).

This rejection of the party form is also coupled with a set of innovative practices the 5SM engages in to mark its difference from traditional political parties. These include the possibility for every Italian citizen who is not affiliated with other political parties to join the 5SM online at no cost; the choice not to hold congresses or institute political organisms that may lead to the 
formation of internal factions and strands; the adoption of a funding structure based on online micro-donations in place of the public reimbursements the 5SM would be entitled to under the Italian law; and the reliance on a networked infrastructure of Meetup groups, Facebook groups, messaging application groups, and other remote forms of association that replace, at least in part, the physical infrastructure of a traditional "brick-and-mortar" party.

If this networked infrastructure has the advantage of being less costly and more accessible to ordinary citizens (with an Internet connection), it also presents significant drawbacks. Indeed in the years 2005-2009, many followers of beppegrillo.it joined the Friends of Beppe Grillo groups without subsequently joining the 5SM. In order to solve the ambiguous status of the Meetups, the 5SM leadership has explicitly barred them from using the official party logo, releasing any statement on behalf of the 5SM, or teaming up with other Meetups at a regional and national level (Fico and Di Battista 2015). On the one hand, such directives respond to the need of drawing a line between the porous and informal boundaries of online communities and the formal boundaries of an organization that in spite of its rejection of traditional parties, is a political party insofar as it runs candidates for public office (Biancalana 2017; Sartori 1976: 63). On the other hand, the political choice to prevent the formation of intermediary bodies is rooted in a vision of digital democracy as enabler of a direct relationship between ordinary citizens and their representatives.

Grillo and Casaleggio see in fact the Internet as a transformative technology whose growing use will ultimately undermine the autonomy of the political class, reducing the representative to a "terminal and executor of the popular body" (Casaleggio and Grillo 2011: 21). It is no accident that the party leaders have criticized the free mandate-a cornerstone of representative democracy - on various occasions, advocating the introduction of direct democracy measures such as online referendums, citizens' initiatives, and recall ballots (Casaleggio 2013; Casaleggio et al. 2013). Because the Italian Constitution does not contemplate these measures, and explicitly protects the free mandate under article 67, the 5SM has threatened to fine those candidates who may not apply the party program once elected into office, or who may refuse to resign if found guilty by a criminal court. ${ }^{3}$ The $5 \mathrm{SM}^{\prime}$ 's commitment to introduce a form of imperative mandate is also evident from the two-mandate limit for all its elected representatives - a measure that is meant to prevent the ossification of a party establishment. Finally, it is also evident in the MPs' choice to refuse The Honorable style (onorevole) and to replace it with the informal title of citizen or spokesperson (portavoce).

This system of checks on the autonomy of representatives is not to be confused, however, with a rejection of the parliamentary institution. On the contrary, the 5SM has often defended the

${ }^{3}$ The 5SM candidates at the European elections of 2014 and at the City of Rome of 2016 vowed to abide by the rules of a Code of Conduct, which they signed off as a contract. The codes include fines of $€ 250.000$ and $€ 150.000$ euros, respectively, for violating the mentioned conditions. In both cases the text mentions the institute of the recall ballot in the United States. Because the Italian Constitution does not contemplate recalls these contracts may be illegal. See:

www.beppegrillo.it/movimento/codice_comportamento_europee.php

www.beppegrillo.it/listeciviche/liste/roma/codice_comportamento_5SMRoma.pdf. 
constitutional centrality of the Parliament and its autonomy from both the executive power and the influence of organized interest groups, be they unions or corporate lobbies. This means that the strategic mission or ideological program of the $5 \mathrm{SM}$ is to eliminate any form of structured mediation between the body politic and its representatives. "Once this process will be accomplished, the space of politics will be free of organized parts, because it will be completely occupied by all citizens" (Caruso 2015: 316-17). In this sense, the 5SM utopian vision of a fully realized digital direct democracy entails nothing less than "the abolition of all political parties" (Weil 2013) and the demise of the professional politician, whose function will be ultimately replaced by the voluntary and temporary participation of all citizens to political life.

In sum, the organizational structure and ideological program of the 5SM suggests that this movement party (Kitschelt 2006) rejects both the function of the traditional political partyunderstood as a necessary intermediary between society and the state-and the autonomy of the party in public office from the will of the electoral body. Thus the 5SM does not see itself as a political organization that mediates between different interests or contending political lines, but as a mere conveyor belt that allows ordinary citizens to participate directly in the legislative process. Central to this shift from politics as a profession to politics as a form of service is the Network (la Rete), which 5SM activists routinely refer to as the ultimate source of decisional power ("la Rete decide" is a well-known 5SM slogan). Although the network of 5SM members is dispersed throughout the Internet, Rousseau is the hub where the network coalesces in what the party rule book describes as the "assembly of the members" (assemblea degli iscritti). ${ }^{4}$ In this context, the term assembly is to be understood metaphorically for two distinct reasons. First, as with any Internetbased community, the members do not meet in a physical location. Second, if Rousseau could support in theory the formation of a distributed assembly, the platform lacks in practice any tool for real-time or asynchronous coordination and communication among the members.

4The party rule book (regolamento) was approved on October 26, 2016, at the end of a mont long consultation. Rousseau registered users were urged to modify the party statute (also known as the "non-statute" to demarcate the 5SM's difference from traditional parties), and choose one of two versions of the new rule book. According to the organizers, 87.213 members voted (64.6\% of the total) for a new rule book that implements a legally valid procedure for the expulsion of party members. The consultation was launched in response to an ordinance of the Tribunal of Naples, which recognized in July 2016 the right of a group of 5SM activists to be reintegrated in the party because illegally expelled. It is to be noted that the Italian law requires the participation of at least $75 \%$ of the members for the modification of a party statute. Although the 5SM claims that the new Rule Book and "Non Statute" are now fully in effect, it is likely that party dissidents will continue to challenge these documents and the expulsion procedures they seek to establish. It is also to be noted that this was the second and last case in which the vote was certified by a third party, the Milan-based company DNV GL Business Assurance Italia (see www.beppegrillo.it/immagini/Lettera\%20di\%20verifica\%20DNV\%20GL.pdf). Such certification demonstrates that the consultation was organized for primarily legal reasons. 


\section{Main Functionalities of Rousseau}

Officially launched in April 2016, Rousseau has been developed at the Casaleggio Associati, a small web marketing company based in Milan, whose current CEO, Davide Casaleggio, is the son of Gianroberto, who passed away in February 2016. After the platform's launch, the company donated it to the Associazione Rousseau, a no-profit organization whose members are Davide Casaleggio himself, two elected representatives of the 5SM, and a former employee of the Casaleggio Associati. Although Rousseau was launched in 2016, a less elaborate version of the platform called the Operating System (Sistema Operativo) existed since October 2013. The Sistema Operativo enabled members to vote for the party primaries and other political matters, discuss draft legislation, and fundraise. Before the launch of the Sistema Operativo, 5SM members voted directly via beppegrillo.it, as is the case with the Parlamentarie, the first online primary elections held in December 2012 to select the MP candidates for the general election of 2013.

In all three cases, 5SM members register online, and acquire the right to access Rousseau with voting power. In theory, becoming a 5SM member is simple. All Italian adult citizens who are not affiliated with other political parties can register via the portal movimento5stelle.it for free. In practice, however, the registration procedure can take months as users often encounter difficulties scanning and uploading their IDs (the scanned image has to be kept within a $150 \mathrm{~KB}$ limit). As I have personally had the opportunity to verify during fieldwork at the 5SM National Meeting of Rimini in September 2017 many 5SM activists and sympathizers, especially of an older age, were not able to pass this stage of the registration process. In spite of these technical difficulties, the 5SM has seen a steady growth of its membership base since 2012. According to data provided by the Beppe Grillo blog, the certified members of the 5SM were 31,162 in December 2012; 48,292 in June 2013; 80,383 in January 2014; 85,408 in February 2014; 87,656 in June 2014; and 135,023 in October 2016. In August 2017, Davide Casaleggio announced that the active users of Rousseau were over 140,000 (Casaleggio 2017).

As compared to the Sistema Operativo, Rousseau has added a number of functionalities. The platform is currently divided in nine areas, which are accessible to all users: Lex Members (Lex Iscritti), Lex Europe, Lex Parliament, Lex Region, Shield of the Net (Scudo della Rete), Fund Raising, E-learning, Sharing, and Call to Action (Figure 1). A tenth area, currently under development, is called Activism. Additionally a "Vote" functionality is activated any time users are called to vote for the primaries, approve the party program, or make other political decisions. Since August 2017, the platform also allows non-members to navigate in guest mode, without voting power and without the possibility of posting comments or submitting proposals. 
Figure 1: The Call to Action area of Rousseau (source: http://rousseau.movimento5stelle.it)

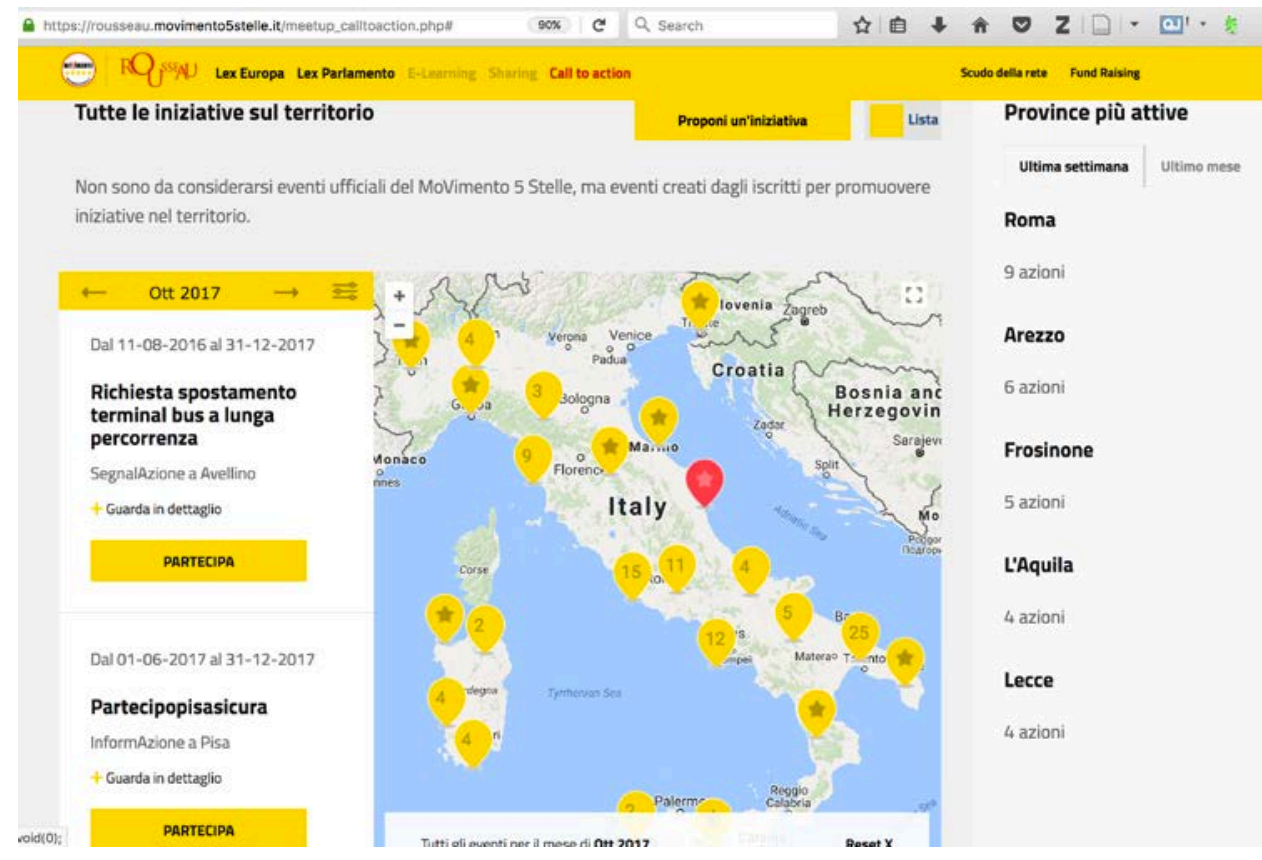

\subsection{Rousseau's Lack of Transparency}

Before delving into the areas I should discuss two important preliminary issues. First, the source code of Rousseau is not available for public inspection. Because one of the Casaleggio Associati's revenue streams is the management of web logs, the company has relied on internal resources to build Rousseau on Movable Type, a content management system and blogging platform developed by the Californian company Six Apart. Although Six Apart has released an open source version of Movable Type, Rousseau runs the proprietary version of the software. This means that it is not possible for programmers and technically literate citizens to verify the code's integrity. This lack of transparency is particularly worrisome. On the one hand it exposes the Casaleggio Associati to the suspicion that the code might hide algorithms that may be used for data mining or marketing purposes (Canestrari and Biondo, 2017: 323). On the other hand, a buggy software increases the chances that electronic attacks may succeed, as it occurred in August 2017, when two hackers claimed to have appropriated sensitive data of the platform users.

Second, and even more worrisome, the Casaleggio Associati has exclusive access to the database of registered voters as well as to the voting records. Because voting in Rousseau is not based on an end-to-end auditable voting system, which is currently considered the most resistant system to vote tampering, the integrity of the vote is hardly guaranteed. An E2E auditable voting system would in fact allow Rousseau users to verify that their encrypted vote has been correctly registered in the database, while preventing administrators from linking the vote record to specific individuals (Ruescas and Deseriis 2017). To be sure, the fact that voting on Rousseau cannot be verified does not mean that it is necessarily manipulated. Yet it is significant that in one of the two circumstances in which a third party certified the vote, the voting operations had to be repeated because of an electronic attack (Movimento 5 Stelle 2013). Further, some 5SM insiders, including an elected MP, have suggested that the online primaries may have manipulated to favor specific 
candidates (Gambaro in Mello 2014; Agostini in Canestrari and Biondo 2017: 300-302). Finally, the fact that the Casaleggio Associati controls a large database of voting records potentially allows the party leadership to profile any Rousseau registered user-including elected representatives - who expresses a preference through a vote.

\subsection{The Democratic Affordances of Rousseau: The Centrality of the Binding Vote}

To give a sense of how accurate such profiles may be, we have to consider that Rousseau users are called to vote several times a year. It is estimated that from December 2012, date of the first online vote, through early 2017, 5SM members have had the opportunity to cast their vote approximately seventy times (Andraghetti 2017). Out of these, forty consultations concerned issues of national and international relevance, ranging from the expulsion of dissident MPs to the possible change of parliamentary group in the European Parliament to the revision of the party statute. Even though data suggest that voter turnout has been declining from an initial $60 \%$ of registered users in December 2012 to an average of 30\% of registered users per consultation in the following years (Mosca and Vaccari 2017) these binding consultations have allowed the 5SM leadership to present Rousseau as a large-scale experiment in direct democracy (Movimento 5 Stelle Europa 2015; Movimento 5 Stelle 2016b) or, more recently, participatory democracy (Casaleggio 2017).

Although participatory democracy and direct democracy overlap in many areas, direct democracy lays a stronger emphasis on the citizens' ability to decide on matters that concern their lives. In contrast, theorists of participatory democracy tend to emphasize the importance of democratic participation in civil society contexts (Pateman 1970), the different levels and intensities of political commitment of each citizen (Dahl 2000), and the centrality of the opinion-forming process to democratic decision making (Della Porta 2013).

In order to understand whether Rousseau embodies a specific conception of democracy, in the remainder of this article I will analyze the platform's “democratic affordances" (Dahlberg 2011), that is, the political processes that the platform enables or disables. It is worth noting that due to its roots in cognitive psychology (Gibson 1977) and interaction design (Norman 1988), the term affordance does not merely describe the material properties of an object or a technology, but the subjective perceptibility of such properties. It follows that a democratic affordance does not strictly coincide with the technical functionalities of a participation platform. Rather a democratic affordance becomes perceivable, and thus usable, when technological capabilities that can theoretically support a wide range of practices are adapted to support a particular model of political participation, which, in the case of Rousseau, means to promote a particular kind of relationship between the represented and the representatives.

To illustrate this point, let me briefly contrast Rousseau to participation platforms such as LiquidFeedback, Loomio, and DemocracyOS. Used within parties such as the German Pirate Party, Podemos in Spain, and the Partido de la Red in Argentina, these platforms are designed to make users' decisions visible to all other users. Yet because in modern political systems vote transparency is incompatible with politically sensitive decisions these platforms have been mostly used for nonbinding consultations and civic initiatives on a local level. If this limits their users' ability to influence high-level decision-making (Mendoza 2015), it also allows them to focus on the 
deliberative processes whereby proposals are initially filtered, contending arguments are heard, compromises are reached, and decisions are eventually made. Thus, on the one hand, these platforms have a limited impact on policymaking and the action of ruling groups. On the other hand, they can facilitate the extension of deliberative skills that are ordinarily the purview of professional politicians to ordinary citizens (Bartlett and Deseriis 2017).

In contrast, Rousseau reduces deliberation to a minimum while foregrounding the binding vote as the decisional moment through which the 5SM members exert their general will, to borrow JeanJacques Rousseau's famous expression. Such choice is deliberate. As Members of Parliament Manlio Di Stefano, Nunzia Catalfo, and Danilo Toninelli noted in their presentations in Palermo, Rousseau has been designed to function as an "operational tool" rather than an outlet for extended discussions among party members. In this context operational means that voting is central to a range of party activities that go well beyond the selection of a ruling group via online primaries. For example, beginning in 2017, Rousseau registered users have been repeatedly invited to vote different sections of the party program (energy, education, foreign policy, labour, defense, and so forth) for the general election of 2018. In this case voting consists in filling single-choice or multiple-choice questionnaires formulated on the basis of expert opinions published on beppegrillo.it. Although each expert's blog posts received dozens, sometimes hundreds, of comments - including those of non-members - the questions were formulated on the basis of the expert's initial opinion, and not on the basis of the collective discussion that unfolded on the blog. Further, whereas in the vast majority of cases the questions proposed solutions to problems indicated by the experts, in one circumstance the blog disavowed the expert, stating the "official position of the $5 S^{\prime \prime}$ in a post scriptum to the expert's post (Movimento 5 Stelle 2017). Such specification produced the paradoxical effect of asserting the official party line (in this case, on the defense program) before the members were consulted on it.

From this angle, it is evident that the 5SM ruling group retains control of the party agenda, allowing members to choose between options they have themselves defined. At the same time, other areas of Rousseau allow members to interact directly with representatives outside of the mediation of traditional party structures. The nature of this interaction, however, needs to be qualified. Indeed, if voting signifies directness and exertion of will (Urbinati 2013), a large part of Rousseau is dedicated to lawmaking, which reintroduces the need for (a controlled) debate while promoting the mediating function of professional lawmakers.

\subsection{Crowdsourced Lawmaking}

Significantly, four of the nine areas of Rousseau (Lex Members, Lex Region, Lex Parliament and Lex Europe) are dedicated to the drafting and discussion of bill proposals. This Web-based parliamentarization of the 5SM is in line with the process of institutionalization that the party has undergone since 2012. Indeed, the extension of parliamentary processes to the Web occurs by and large via a "crowdsourcing" of bills of law that channels the activism of the party base within specific boundaries. Lawmaking entails in fact a series of activities (such as hiring specialized staff, consulting expert knowledge, prioritizing certain bills, and creating tactical alliances with other political forces) that are strategically left out of Rousseau. The exclusion of these activities from the 
platform's affordances ensures that the MPs retain the freedom to determine which bills should be introduced into Parliament, which should be given priority, and how they should be crafted. At the same time, the representatives have access to a wide range of opinions that keep them in touch with the party base's moods and orientations.

The three areas in which the asymmetrical relationship between representatives and members is most evident are Lex Region, Lex Parliament, and Lex Europe. Even though different jurisdictions can activate different constituencies (for example, users can only visualize the region where they reside) the three areas present identical functionalities so I will discuss their structural affordances as one, focusing in particular on Lex Parliament.

As soon as a 5SM representative has finished drafting a bill she is required to upload it to Lex, where members have 60 days at their disposal to discuss it. All bills are introduced by a short explicative video and text summary and users are invited to comment using one of five options: Addition (Integrazione), Modification, Objection, Suggestion, and Defect of Form. A sixth button allows for Off Topic comments (Figure 3). Members can also vote their preferred comments (using one to five stars) but cannot reply to other comments. As noted, this means that these areas are designed to enable an exchange of opinions between constituents and representatives (who have the right to reply) but not among the constituents, whose conversations are relegated to the Beppe Grillo blog, Meetups and Facebook groups, and other forums of the 5SM galaxy.

\section{Figure 2: The categorization of comments on a bill proposal (source: http://rousseau.movimento5stelle.it)}

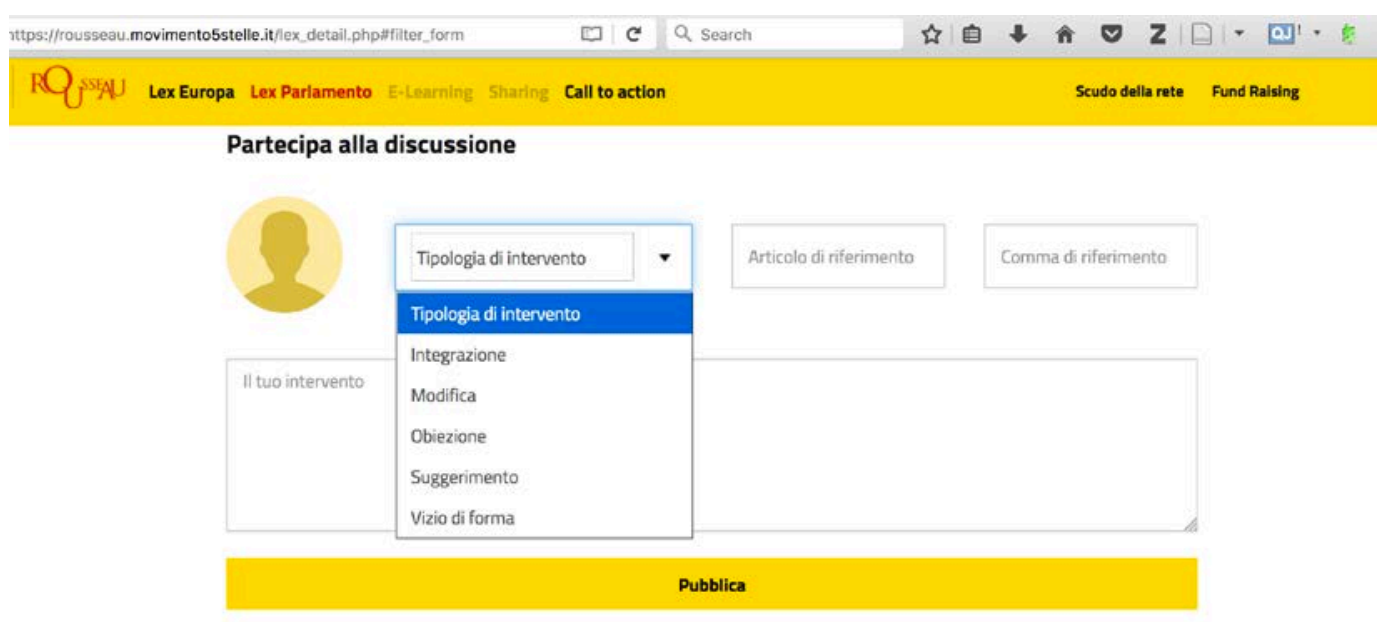

If the comment structure of the platform is designed to produce a direct, but ultimately vertical relationship between representatives and represented, it is worth noting that no other Italian party opens up draft legislation to the input of its members - certainly not at this level of granularity. To give a sense of the scope and participation in Lex Parliament, from January 2014 through November 2017, the 5SM deputies and senators uploaded a total of 324 draft bills (an average of 81 bills per year), generating over 70,000 comments. It has been noted that the number of comments per bill has been steadily declining, from an average of 446 per bill in 2014 to an average of 144 per 
bill in 2016 (Mosca and Vaccari 2017: 228). However, the average of 2014 is heavily skewed by the unusually high participation on the first four bills, which received a total of 14,211 comments (out of which 7,447 on a single bill). Once we discount the novelty effect associated with the introduction of a new technology, the decline in participation appears less marked.

One of the main issues of Lex Parliament is the ostensible lack of feedback on the vast majority of the comments. Although many comments do not require a response, the rate of reply is only $5 \%$ (Mosca and Vaccari 2017: 230), varies greatly from MP to MP, and does not seem to follow consistent criteria or guidelines. According to House representative Manlio Di Stefano-who oversees Lex Parliament in collaboration with senator Nunzia Catalfo-the MPs are supposed to use "the most significant comments" to amend the draft bill. Because in the absence of further specifications significance remains a highly subjective criterion, Di Stefano (Figure 4) admits that the selection process is ultimately determined by the $5 \mathrm{SM}$ 's political culture:

It is obvious that filtering is, at a basic level, political. If, for example, on the [Beppe Brillo] blog and in our movement culture, we have conducted a pacifist struggle for ten years, it is obvious that the most significant comments won't be the ones that go in the opposite direction. And why? Because, as we have always said, the Five Star Movement is founded upon ideas, and ideas are also something that we hand down to each other as a political line, a political line that is postideological but that nonetheless has a strong basis in our identity (author's audio record, 2016).

Figure 3: Manlio Di Stefano and Nunzia Catalfo present Lex Parliament, Palermo, September 25, 2016. (photo: Marco Deseriis)

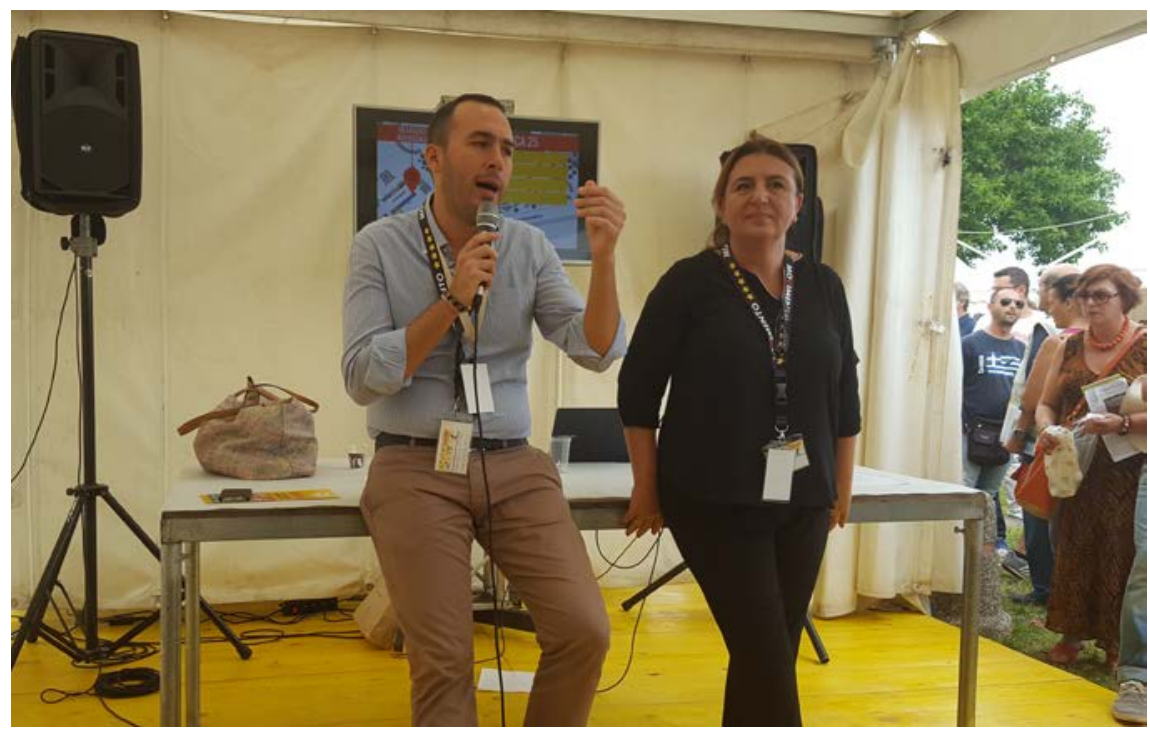

Thus Di Stefano attributes to the MPs the prerogative to guard the identity of the 5SM and assumes that the party has a univocal and widely shared political line on every issue. At the same time, it must be noted that the platform affordances reduce to a certain extent the margins of subjective intervention. After the end of the discussion phase, each MP is supposed to publish a copy of the revised bill that she will introduce in the appropriate parliamentary committee, along with a conclusive report that explains which comments have been used an how. Significantly, only 23 bills out of 324 (7.1\% of the total) have reached the publication stage since 2014 . If this may be 
due to a variety of factors (ranging from the MP's neglect to update the status of the proposal to the political choice of withdrawing the bill) the quality and depth of the conclusive reports is also highly variable. Only 6 of the 23 reports acknowledge in fact individual contributors, or explain how the MP has modified specific articles or paragraphs in response to the users' comments.

Whether this reduced feedback is a byproduct of lack of internal resources or a willful choice of some representatives to ignore the contributions of the party base, the 5SM party statute does not require elected representatives to respond to the members' comments. Thus, from a normative standpoint, Lex Region, Lex Parliament, and Lex Europe do not reduce the autonomy of elected representatives, giving them ample discretionary power. Were the 5SM or the Italian Parliament to allocate sufficient staff members and internal resources, the rate of response to the citizens' queries would certainly increase, and with it the motivation of citizens to participate. (Ironically, however, because one of the 5SM's flagship campaigns - if not its very raison d'etre - is to cut the costs of the Italian political system, the proposal of increasing public spending to support citizen participation in lawmaking will probably have to come from other political forces.)

\subsection{Lawmaking from Below, a Complex Matter}

This insufficient tasking of internal resources is also evident in the management of Lex Members (Lex Iscritti), the area of Rousseau that allows all Rousseau users to submit their own ideas for a bill of law. From July 2016 through June 2017 Rousseau users have submitted a total of 6223 proposals to Lex Members, forcing the staff of Danilo Toninelli, the House representative who oversees this area, to suspend the consultation process for several months (Toninelli in Open Day Rousseau 2017, min. 40:30). ${ }^{5}$ Turning an idea into an actual bill of law is in fact an elaborate, selective, and competitive process that is divided in six distinct phases: drafting, screening, voting, tutoring, discussing, and introducing the actual bill into Parliament.

5 The last consultation on Lex Members was held on June 28, 2017. According to Toninelli, in late September 2017 the staff overseeing Lex Members still had to process proposals uploaded in February 2017. As of October 30, 2017, the consultation process has not been resumed yet. 
Figure 4: Danilo Toninelli presents Lex Members [Lex Iscritti], Rimini, September 23, 2017 (photo: Marco Deseriis)

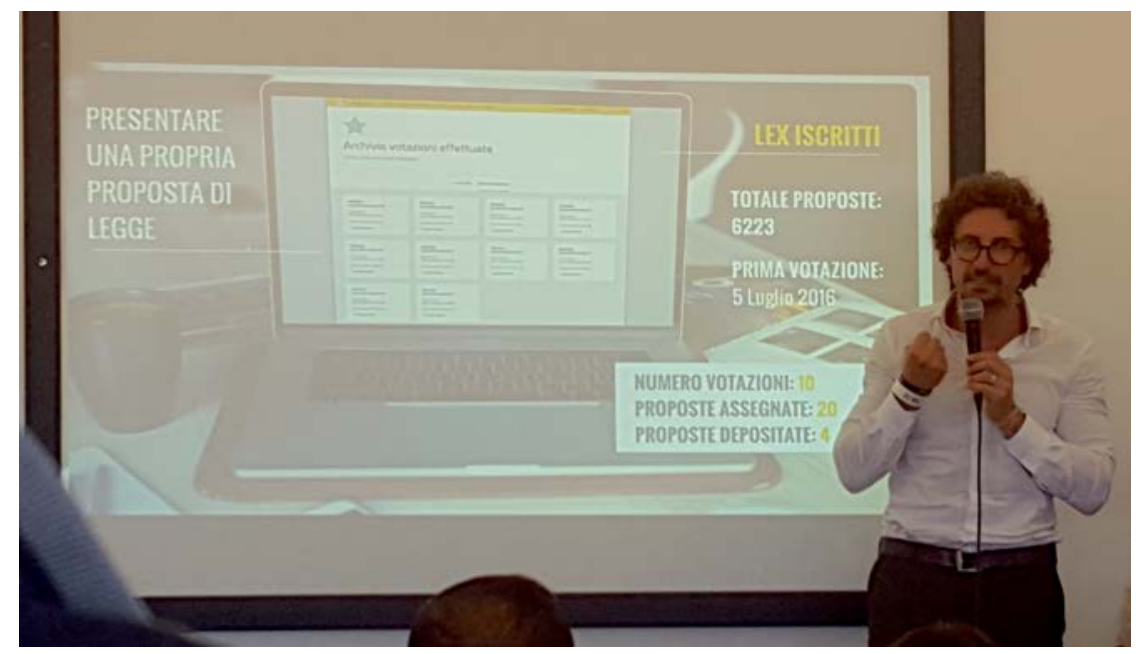

In phase one, members draft a proposal for a bill of law. A form asks for a brief description of the bill and of its stated objective, an analysis of preexisting Italian legislation on the same subject, a comparison with similar legislation that may exist abroad, and the expertise of the proponent. Although this is not an insignificant amount of work, a cursory look at the proposals that are routinely uploaded clearly shows that the members do not spend much time researching preexisting or comparable legislation. Ultimately what matters is a clear description of the proposal and of its objective. In this respect, the threshold of access is quite low, which meets the stated purpose of making this area of Rousseau accessible to all citizens with an Internet connection and a 5SM membership.

The second phase begins as soon as the 5SM MPs screen the uploaded proposals. According to Toninelli, the uploaded proposals have to meet four requisites in order to pass the screening phase: constitutionality, jurisdiction (as the national Parliament may not be competent on the proposed bill), financial feasibility, and consistency. The latter means that new proposals must neither duplicate preexisting 5SM-sponsored bills on the same subject nor contradict proposals that have already been approved via Lex and introduced into Parliament in the prior 24 months. Further, the proposals that are

very complex, both from an ethical and juridical standpoint... are treated as complex matter [material complessa] ... Let us suppose that you make a proposal that is either ethically very delicate (and on which the Movement has never expressed a position and is not part of the program) or that is very elaborate. This proposal goes on a separate track, we find experts that can explain it ... and then it is subjected to one or multiple voting rounds. This path ensures that the initial proposal, qua complex matter, can be completely changed [stravolta] because the actual position of the Movement on that topic will take shape through this process. Paradoxically the proposal could be voted in a way that if not opposite to the initial formulation, otherwise the proponent would withdraw it, could be completely different (Toninelli in Di Stefano 2016, min. 26:00). 
Laying out an argument that is similar to Di Stefano's remarks on the political nature of filtering, Toninelli's words suggest that even in the direct democracy area of Rousseau the MPs deploy a series of checks that ultimately reinforce the representatives' prerogative to guard the identity of the 5SM. The "multiple voting rounds" to which a complex proposal would be subjected are in fact all internal to the parliamentary group, and so far none of the proposals that have been purportedly "treated as complex matter" have been opened up to a wider party discussion.

The significant nature of this filtering process is also clear in quantitative terms. Out of the 6223 proposals uploaded on Lex Members, only 1079 have passed the screening phase. This means that approximately $83 \%$ of the proposals have been rejected because they do not meet the four criteria outlined above or because deemed complex matter. The rejected proposals, however, are not accessible for consultation to Rousseau users, leaving the screening process unchecked and unverifiable.

The third phase consists in voting. Every 2-6 weeks all registered users receive an email that invites them to vote a new batch of proposals available in Lex Members. The number of proposals per batch has been ranging between a minimum of 89 and a maximum of 193, with most batches containing less than 100 proposals. Voters have time from $10 \mathrm{am}$ to $7 \mathrm{pm}$ on a given day to review the proposals and cast five preferences (all voting in Rousseau usually occurs within the same time window). The two proposals that receive the highest number of preferences move to the tutoring phase. Before discussing the tutoring phase, it is worth noting that the email notification announcing the start of voting is usually sent few hours, sometimes even few minutes, in advance. Whereas the short notice is due, as noted above, to security concerns, the lack of forewarning is likely to reduce engagement as members have a short time window at their disposal to review the proposals and cast their vote. Significantly, however, voter turnout in Lex Members has been ranging between $12 \%$ and $15 \%$, but not declining as is the case with Lex Parliament and the other consultative areas of the platform.

The fourth phase begins when the two winning proponents are assigned a tutor by the 5SM parliamentary group. According to Toninelli, the tutor's task is exclusively to transform a proposal written in a non-juridical language into an actual bill of law (disegno di legge). This translation fixes some legal boundaries but, contrary to the proposals that are labeled "complex matter," it cannot in any way change the sense and intention of the original proposal. Once the bill is ready, an MP presents it in the Lex Parliament area. Significantly, the video presentation of a Lex Membersinspired bill features both the original proponent and the MP. In this fifth phase, the bill is opened up for feedback to all Rousseau users for sixty days as any other bill. Finally, it is introduced in a committee, from where it is supposed to begin its regular parliamentary path. (At the moment, however, because the 5SM is at the opposition, it is very unlikely that any of the twenty bills that have been approved via Lex Members will be passed, or even scheduled for a vote).

\subsection{Peer Mentoring}

Rousseau also plays a role in helping 5SM members who run for elections, or have been newly elected at a local level, to acquire important administrative competences. The two main areas that 
are dedicated to this effort are E-learning and Sharing. The former is a series of informative video tutorials led by Enrica Sabatini (Figure 5), a 5SM councillor in the City of Pescara, and senator Nicola Morra. The tutorials go from the macro to the micro, addressing the constitutional regulation of local administrative branches, the role of their governing bodies, all the way "down" to the functioning of committees and departments. After taking the tutorial, aspiring councillors and mayors can take an online test to verify their level of competence.

Finally, Sharing is the area of Rousseau that is most used by local M5S administrators, who use it to upload and share administrative acts across the national territory. As of late October 2017, the area hosts 2,370 administrative acts, which can be searched by typology (interpellation, resolution, regional bill, order of business, and so forth) or by tags and keywords. After Marco Piazza and Max Bugani, two councillors elected in the City of Bologna, ended their presentation of this area in Palermo, an animated discussion began with the public. It soon became clear that many newly elected 5SM councillors had initially found it difficult to familiarize themselves with the bureaucratic machinery of their cities - something that political opponents have often exploited to their advantage. By allowing city and regional councillors to share resolutions and trade tips on how to introduce them, Sharing ensures that local representatives with little administrative experience can quickly fill experience gaps and compete with their political counterparts on an equal foot.

Figure 5: A tutorial in the E-learning area of Rousseau (source: http://rousseau.movimento5stelle.it)
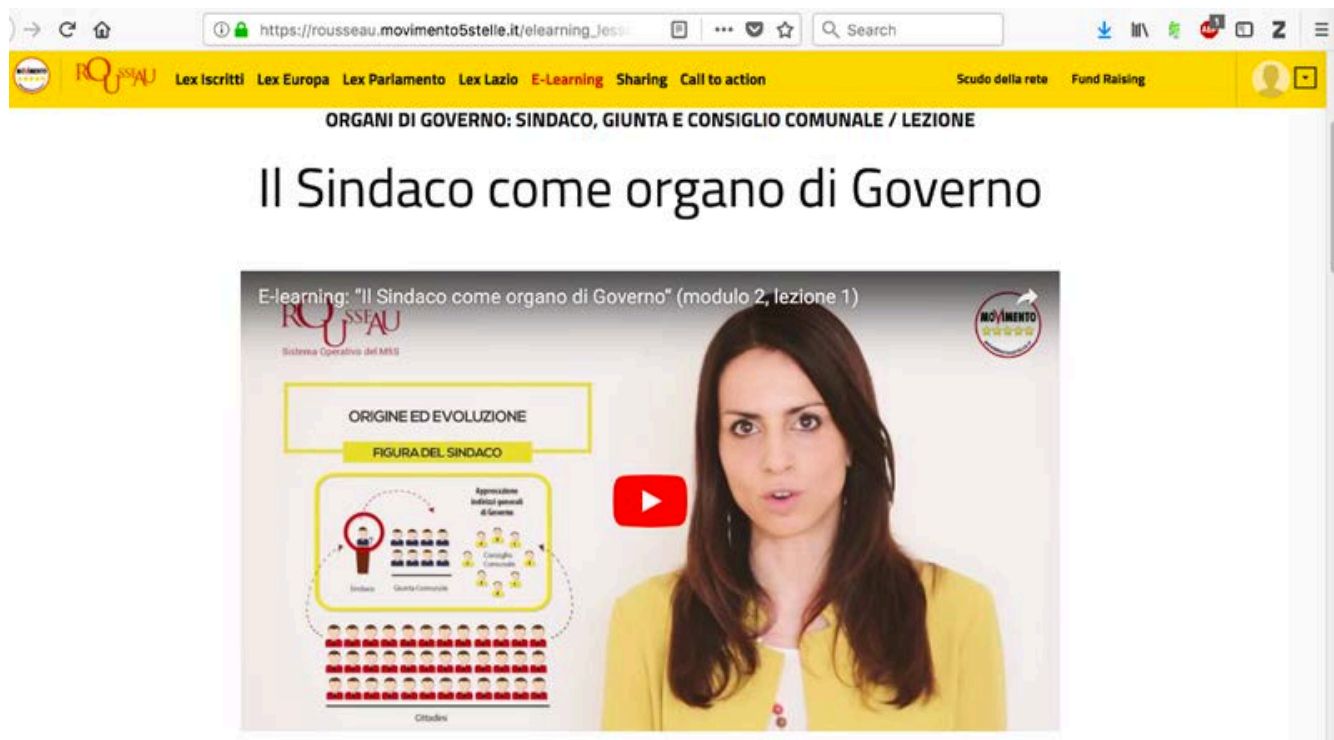

Overall, E-learning and Sharing are meant to function as peer mentoring tools for an emerging class of citizens at their first institutional experience. In this respect, Rousseau functions also as a co-training platform, which replaces to a certain extent a political party's cadre school. To be sure, large political parties can offer their perspective cadres training programs that go well beyond counseling for inexperienced administrators. Yet Rousseau could develop this more strictly political educational function in other areas of the platform (including the still incubating Activism) in the future. 


\section{Conclusion}

In conclusion, in this article I have argued that Rousseau is a platform (or an "operating system," in the 5SM parlance) wherein different conceptions of democracy coexist side by side. Although the 5SM leaders routinely refer to Rousseau as a direct democracy platform, my wager is that Rousseau supports an emerging "direct parliamentarianism." This oxymoron has been originally used in the German context, in conjunction with the use of Liquid Democracy software such as LiquidFeedback and AdHocracy. ${ }^{6}$ However, it is particularly apt to describe the democratic affordances of Rousseau. Within the platform we can in fact observe the coexistence of two distinct, if not contradictory, conceptions of democracy.

On the one hand, Rousseau extends to the Web some of the procedures of a key institution of liberal democracy such as the parliament. As we have seen, the party in public office consults the party on the ground on proposed legislation while remaining free to decide which suggestions to implement and which to discard. On the other hand, Rousseau implements decision-making procedures that are more typical of direct democracy. These include the possibility for party members to propose their own legislation, cast votes on critical parliamentary decisions, and vote on the expulsion of activists and elected representatives accused on violating the party's code of conduct. From this angle, the elected representatives are more similar to delegates or spokespersons (as they call themselves) of the 5SM polity.

Although these two models are potentially incompatible, Rousseau allows them to coexist by implementing a set of affordances that selectively enable specific elements of a decision-making process. As we have seen, central to the establishment of a direct relationship between members and representatives is the binding vote. Most times, however, binding votes are called on "questions that are defined ex-ante by the platform managers" (Mosca 2015: 42) as is the case with the expulsion of dissidents and the definition of the party program. Thus the disconnection between the discussions that unfold on Beppe Grillo's blog and the votes on Rousseau, as well as the lack of in-platform discussion tools, prevents 5SM members from influencing the party agenda before collective preferences are aggregated through a vote.

To be sure, deliberation is not completely absent from Rousseau. As we have seen, Lex allows users to comment on draft legislation and some MPs respond consistently to the users' comments. However, the lack of clear norms regulating this aspect of the MPs' activity produces a highly variable rate of response from MP to MP, and a modest use of an accountability tool such as the

${ }^{6}$ Liquid Democracy is an emerging model of participatory democracy that is based on the principle of transitive delegation by proxy votes. Rather than assuming that all citizens are equally knowledgeable of every issue, LD software allow users to delegate their vote to other users by topic, facilitating the emergence of networks of trust (Behrens et al. 2015). Whereas parties such as the German Pirate Party, Die Linke and the SPD have made use of LiquidFeedback and AdHocracy only the Berlin Pirate Party has made use of the former to elaborate the party platform and receive input from the members on legislative activity in the Berlin Parliament. 
final report. As we noted, this compression of the deliberative moment, or its relegation to discussions that are not clearly linked to the platform's decisions, has concrete political effects. For example, users are not allowed to discuss whether there is enough ground to call a vote on the expulsion of a party member, which political decisions should be opened to the party base's input, or how the party program should be crafted. To allow for this kind of agenda-setting debates would mean to create the conditions of possibility for the emergence of alternative and potentially conflicting political lines that would need to be mediated. But as we have seen the party in central office sees no value in the internal dialectic and intermediating function of traditional party organisms such as executive committees, regional councils or federations of local Meetups, national assemblies and congresses.

In sum, in compartimentalizing deliberation and decision-making, Rousseau tends to separate what Chantal Mouffe calls the political - that is, the unfiltered antagonisms that may exist within society-from politics, understood as the institutional framework within which such conflicts are channeled and regulated (Mouffe 2000: 101). Thus it is only by leaving outside of the platform these antagonistic positions that the 5SM representatives can entertain an ostensibly unmediated relationship with their constituents. Differently put, this variant of direct parliamentarianism reserves the deliberative, and strictly "parliamentary" moment to the elected representatives and the party leaders, leaving to the party base the task of choosing between alternatives that have been decided elsewhere.

Finally, I would like to conclude this article with three brief recommendations. The first concerns the initial observation that Rousseau's source code is not open. If the 5SM wants to turn Rousseau into a model for participatory democracy it needs to be much more transparent in this area. In an influential book of the late 1990s, Lawrence Lessig coined the dictum "code is law" (Lessig 1999). If the citizens-who-want-to-become-state are teaching themselves the legal codes that allow them to run the state machine, the centrality of the Internet to the 5SM constitution and organization suggests that they also need to familiarize themselves with the underlying digital codes that regulate their remote interactions. From this perspective, for Rousseau to be a truly democratic platform, the release of its source code-the equivalent of its digital constitution-can no longer be postponed. Second, in order to increase vote transparency and vote verifiability, the platform managers at the Casaleggio Associati should outsource all voting operations to a third party. Podemos, for example, outsources all Internet voting to a Spanish company that makes use of an E2E auditable voting system. Whereas this would not completely eliminate the risk of vote tampering, it would reduce it by allowing individual voters to verify that their vote has been counted as casted. Further, such move would dispel the possibility that Rousseau users may be internally profiled.

Third, as we have seen, the consultative areas of Rousseau (Lex Region, Lex Parliament, and Lex Europe) have witnessed a slow but undeniable decline in participation. In contrast, the direct democracy area Lex Members has been steadily participated, but its operativity has been suspended for several months. These data suggest that the party on the ground's demand to participate is not entirely met by the party in public office, and not adequately supported by the party in central office. In this respect, staffing the MPs with multiple assistants in charge of 
responding to comments on draft legislation, requiring all MPs to post detailed reports on the revised bills, and embedding deliberative and collaborative tools within the platform, are three preliminary steps that could help produce a form of direct parliamentarianism where deliberation is not sidelined and divorced from decision making, but allows for the development of truly participatory and collaborative forms of lawmaking.

\section{References}

Andraghetti, L. (2017). La domanda che nessuno fa al M5S: Chi certifica i voti online? Lettera 43. February 7. Retrieved October 30, 2017, from www.lettera43.it/it/articoli/politica/2017/02/07/la-domanda-chenessuno-fa-al-m5s-chi-certifica-i-voti-online/208333/

Bartlett, R., \& Deseriis, M. (2016). Loomio and the Problem of Deliberation. Open Democracy. December 2. Retrieved October 30, 2017, from www.opendemocracy.net/digitaliberties/marco-deseriis-richardbartlett/loomio-and-problem-of-deliberation.

Behrens, J., \& Kistner, A., \& Nitsche, A., \& Swierczek, B., \& Deseriis, M. (2015). Liquid Democracy, Its Challenges and Its Forebears. Open Democracy. October 9. Retrieved October 30, 2017 from www.opendemocracy.net/can-europe-make-it/jan-behrens-axel-kistner-andreas-nitsche-bj\%C3\%B6rnswierczek-marco-deseriis/liquid-de.

Biancalana, C. (2017). Reshaping Political Organisation and Participation: The Use of the Internet in the Five Star Movement. Paper presented at the $31^{\text {st }}$ Italian Society of Political Science (SISP) conference, Urbino, September 14-16.

Canestrari, M., \& Biondo, N. (2017). Supernova: Com'è stato ucciso il Movimento 5 Stelle. Self-published.

Bordignon, F., \& Ceccarini, L. (2015). The Five-Star Movement: A Hybrid Actor in the Net of State Institutions. Journal of Modern Italian Studies, 20(4), 454-473.

Caruso, L. (2015). Il Movimento 5 Stelle e la fine della politica. Rassegna Italiana di Sociologia, 46(2), 315-340.

Casaleggio, D. (2017). "Presentazione del \#NuovoRousseau: Participate! Don't delegate." Presentation of the new Rousseau at the Associazione Stampa Estera, Rome. August 2. Retrieved October 30, 2017, from www.ilblogdellestelle.it/presentazione_del_nuovorousseau_participate_dont_delegate.html.

Casaleggio, G., \& Grillo, B. (2011). Siamo in guerra. La Rete contro i partiti, Milano: Chiarelettere.

Casaleggio, G. (2013). New Media and the Future of Politics. Presentation at Forum Ambrosetti, Cernobbio, 8 September. Video retrieved on October 30, 2017, from www.polisblog.it/post/152941/casaleggio-ilvideo-integrale-dellintervento-di-cernobbio.

Casaleggio, G., \& Fo, D., \& Grillo, B. (2013). Il grillo canta sempre al tramonto. Dialogo sull'Italia e il movimento 5 stelle. Milano: Chiarelettere.

Dahl, R. A. (2000). On Democracy. New Havem, CT: Yale University press.

Della Porta, D. (2013). Can Democracy Be Saved? Cambridge: Polity. 
Di Stefano, M. (2016). Manlio Di Stefano (M5S) per LEX Iscritti da \#Italia5Stelle a Palermo al Villaggio Rousseau. Youtube video. September 29. Retrieved October 30, 2017, from www.youtube.com/watch? $\mathrm{v}=\mathrm{gKNmN9Ovcsk}$.

Fico, R., \& A. Di Battista. (2015). Lettera ai Meetup. July 19. Retrieved October 30, 2017, from www.beppegrillo.it/2015/07/lettera_ai_meet_up.html.

Katz, R., \& Mair, P. (2002). The Ascendancy of the Party in Public Office: Party Organizational Change in Twentieth-Century Democracies. In R. Gunther, J. R. Montero and J. Linz (Eds.), Political Parties: Old Concepts and New Challenges. Oxford: Oxford University Press.

Kitschelt, H. (2006). Movement Parties. In R. S. Katz and W. Crotty (Eds.), Handbook of Party Politics, London: Sage.

Lessig, L. (1999). Code and Other Laws of Cyberspace. New York: Basic Books.

Manucci, L., \& Amsler, M. (2017). Where the wind blows: Five Star Movement's populism, direct democracy and ideological flexibility. Italian Political Science Review / Rivista Italiana di Scienza Politica. Published online 6 November. https://doi.org/10.1017/ipo.2017.23.

Mello, F. (2013). Il lato oscuro delle stelle. La dittatura digitale di Grillo e Casaleggio. Testimonianze, documenti e retroscena inediti. Reggio Emilia: Imprimatur.

Mello, F. (2014). Un altro blog è possibile. Democrazia e Internet ai tempi di Beppe Grillo. Reggio Emilia: Imprimatur.

Mendoza, N. (2015). Liquid Separation: Three Fundamental Dimensions within LiquidFeedback and other Voting Technologies. JeDEM - eJournal of eDemocracy and Open Government, 7 (2), 45-58.

Mosca, L. (2014). The Five Star Movement: Exception or Vanguard in Europe? The International Spectator, 49(1), $36-52$.

Mosca, L. (2015). Problemi e limiti del modello organizzativo 'cybercratico' nell'esperienza del Movimento 5 Stelle. Ragion Pratica, 44 (1), 37-52.

Mosca, L., \& Vaccari, C. (2017). La progressiva ibridazione dei repertori comunicativi del Movimento. In P. Corbetta (ed.), M5s. Come cambia il partito di Grillo (pp. 195-237). Bologna: Il Mulino.

Mouffe, C. (2000). The Democratic Paradox. London and New York: Verso.

Movimento 5 Stelle. (2013). Presidente della Repubblica a 5 Stelle \#iorivotoilmiopresidente. April 12. www.beppegrillo.it/2013/04/presidente_dell_2.html.

Movimento 5 Stelle Europa. (2015). Il M5S applica la democrazia diretta in UE. April 15. Retrieved October 30, 2017, from www.beppegrillo.it/2015/04/il_m5s_applica_la_democrazia_diretta_in_ue.html.

Movimento 5 Stelle. (2016). Non Statuto. Version of September 26. Retrieved October 30, 2017, from https://s3-eu-west-1.amazonaws.com/materiali-bg/Regolamento-Movimento-5-Stelle.pdf.

Movimento 5 Stelle. (2016b). 5 giorni a 5 Stelle: democrazia diretta con Rousseau e Lex Iscritti. Il Blog delle Stelle. May 28. Retrieved October 30, 2017, from www.ilblogdellestelle.it/5_giorni_a_5_stelle_democrazia_diretta_con_rousseau_e_lex_iscritti.html. 
Movimento 5 Stelle. (2017). \#ProgrammaDifesa: Le Risorse Umane. May 5. Il Blog delle Stelle. Retrieved October 30, 2017, from hwww.ilblogdellestelle.it/programmadifesa_le_risorse_umane.html.

Open Day Rousseau. (2017). Villaggio Rousseau. Youtube video. September 23. Retrieved October 30, 2017, from www.youtube.com/watch?v=cpcSJcb6Mkk.

Passarelli, G., \& Tronconi, F., \& Tuorto, D. (2017). “Chi dice organizzazione dice oligarchia”: cambiamento e contraddizioni della forma organizzativa del Movimento. In P. Corbetta (ed.), M5s. Come cambia il partito di Grillo (pp. 163-194). Bologna: Il Mulino.

Pateman, C. (1970). Participation and Democratic Theory. Cambridge: Cambridge University Press.

Rizzo, S. and G. A. Stella. (2007). La casta. Così i politici italiani sono diventati intoccabili. Milano: Rizzoli.

Ruescas, D., \& Deseriis, M. (2017). AgoraVoting/nVotes. Open Democracy. 4 March. Retrieved October 30, 2017, from www.opendemocracy.net/marco-deseriis-david-ruescas/agora-votingnvotes.

Sartori, G. (1976). Parties and Party Systems: A Framework for Analysis. Cambridge: Cambridge University Press.

Scanzi, A. (2008). Ve lo do io Beppe Grillo. Milano: Mondadori.

Tarchi, M. (2015). Italia Populista. Bologna: Il Mulino.

Tronconi, F. (ed.). (2016). Beppe Grillo's Five Star Movement: Organisation, Communication and Ideology. London and New York: Routledge.

Urbinati, N. (2013). Democrazia in diretta. Le nuove sfide della rappresentanza. Milano: Feltrinelli.

Weil, S. (2013 [1950]). On the Abolition of All Political Parties. New York: New York Review of Books.

\section{About the Author}

Marco Deseriis

Marco Deseriis is Marie Curie Fellow in the Institute of Humanities and Social Sciences at the Scuola Normale Superiore in Florence, Italy and Assistant Professor in the Program in Media and Screen Studies at Northeastern University, Boston, USA. His current research project analyses the political values embedded in the affordances of participation platforms such as Loomio, Rousseau, and Liquidfeedabck, and their use within parties such as Podemos, Five Star Movement, and the Pirate Parties. 